Website: http://jsci.utq.edu.iq

Email: utjsci@utq.edu.iq

\title{
Situation of Rabies in Iraq: A retrospective study 2006-2010
}

\author{
Maral Fathalla Thabit \\ Community Health Department - Medical Technology Institute
}

\section{Abstract:}

Rabies is a highly fatal viral zoonotic disease that is transmitted to human body via the saliva of infected mammals. It is endemic in Iraq especially in rural areas. A cross-sectional retrospective study was carried out in order to obtain 5 year analysis of rabies cases (2006-2010) in the zoonotic section of Center of Communicable Disease Control (CDC), Baghdad city during January 2011. All case records of diagnosed human rabies admitted in different Iraqi governorates hospitals were reviewed and then statistically analyzed. The results showed that the total number of registered rabies cases in Iraq during the included study period was equal to (106) cases, the highest number (27) cases was during the year (2009). The epidemiological profile of patients, showed the predominance of males(91) cases compared to females (15) cases. People at risk were children below ten years of age (35.8\%). Distribution of rabies cases according to different Iraqi governorates was highest in Baghdad city (17.92\%) and this was directly related to the highest number of dog bite victims (18.12\%) also in Baghdad city, while the monthly distribution of registered rabies cases showed no evident seasonal variation.

Recommendations was suggested for health education to increase awareness of people towards the problem, control of stray dogs and incorporate rabies control within the activities of primary health care activities.

\section{Introduction:}

Rabies is a highly fatal zoonotic disease that causes severe destruction of central nervous system of all warm-blooded animals (1), it is a disease transmitted via the saliva of infected mammals (2).The principle vector of the virus is the dog although wild animals can also infect humans (3). The primary mode of transmission is through the bite of infected animals, Albert licking and scratching can also transmit the disease (4).

The annual number of deaths, world-wide caused by rabies is estimated to be 55,000, mostly in rural areas of Africa and Asia (5). An estimated 10 million people receive post- exposure treatments each year after being exposed to rabies suspected animals (6).It is endemic in Iraq especially in rural areas (75\%). Dogs are the main animals to be affected in Iraq and may induce the disease in human by dog bite (7).

Thousands of human deaths from Rabies occur annually despite availability of effective vaccinations for humans following exposure (8).

Usually people with rabies start to notice the early symptoms about 3-12 weeks after being bitten or scratched; however, symptoms may be delayed by many years giving a false illusion that the danger has passed (9). The disease progresses from nonspecific prodromal phase to paresis or paralysis, spasms of swallowing muscles can be stimulated by the sight, sound, and perception of water (hydrophobias), delirium and convulsion can 
develop, followed by coma and death (10). Death (10).Laboratory diagnostics of the disease were inaccessible in Iraq. All diagnosis was based on the clinical picture of the disease. In spite of being the main source of infection, dogs have only been vaccinated sporadically (11).

Rabies in humans can be prevented by appropriate post-exposure prophylaxis (PEP), a treatment not always available and affordable in resource limited countries. Human rabies can also be prevented through vaccination of the animal vectors (12). Although dogs are the main reservoir in developing countries, the epidemiology of the disease differs sufficiently from one region or country to another to warrant the medical evaluation of all mammal bites(13);that's why the researcher aimed to generate baseline information, on the magnitude of rabies in the country, also to obtain information on the epidemiology of rabies in Iraq to create awareness among policymakers and the public at large, also useful in planning and implementing national rabies control and prevention measures.

\section{Patients and Methods:}

A cross-sectional retrospective study was carried out during January 2011, in the zoonotic section of CDC in Baghdad city, all case records of diagnosed rabies cases admitted in different Iraqi governorates hospitals during the period of Ist January to 31 December 2010 were reviewed, because there is a unit of zoonotic diseases in each governorate responsible about collection of data on rabies, dog bites, the data for fatal human rabies was informed to the CDC after developing the signs and history of animal bite from Fever hospitals in different Iraqi provinces and districts. All data that sent to zoonotic section in CDC in Baghdad city for analysis. The information gathered included name of patient, age, sex, residency, date of admission, and type of biting animal, also information was obtained on the number of dog bite attacks per month and year along the same period of the study in different Iraqi governorates. We choose 5 years of data for analysis that would supply sufficient event number, to enable us to sniff out any seasonal variation in rabies admissions. All data obtained were statistically analyzed by using tests of percentages, proportions and Bar charts.

\section{Results:}

The total number of rabies cases per 5 years of the study equal to 106 cases, distributed as 91 males and 15 females. The male to female ratio is $6: 1$; the highest number (27) cases were during (2009). (Table 1)

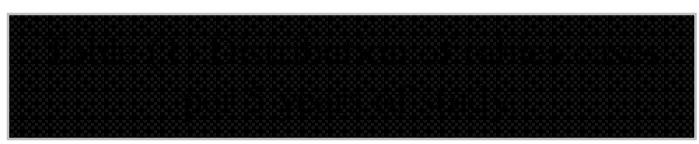

\begin{tabular}{|c|c|c|c|}
\hline year & $\begin{array}{c}\text { No. } \\
\text { males }\end{array}$ & $\begin{array}{c}\text { No. } \\
\text { females }\end{array}$ & Total \\
\hline 2006 & 15 & 3 & 18 \\
\hline 2007 & 19 & 3 & 22 \\
\hline 2008 & 12 & 4 & 16 \\
\hline 2009 & 25 & 2 & 27 \\
\hline 2010 & 20 & 3 & 23 \\
\hline Total & 91 & 15 & 106 \\
\hline
\end{tabular}

The distribution of rabies cases according their age is demonstrated in table (2)

Table (2) Percentage of cases of rabies according to age groups.

\begin{tabular}{|c|c|c|}
\hline Age(Years) & No & $\%$ \\
\hline$<10$ years & 38 & 35.8 \\
\hline $10-19$ & 35 & 33 \\
\hline $20-29$ & 9 & 8.4 \\
\hline $30-39$ & 11 & 10.3 \\
\hline$>40$ & 13 & 12.2 \\
\hline Total & 106 & $100 \%$ \\
\hline
\end{tabular}


The results shows that people at risk were mainly children < 10 years $(35.8 \%)$, followed by teen age group (33\%). Figure (1) shows that during the 5 years of the study, the highest number of rabies cases 19 (17.92 \%) was in Baghdad city, followed with equal number $(17,16.03 \%)$ in both Babyle and Basrah.

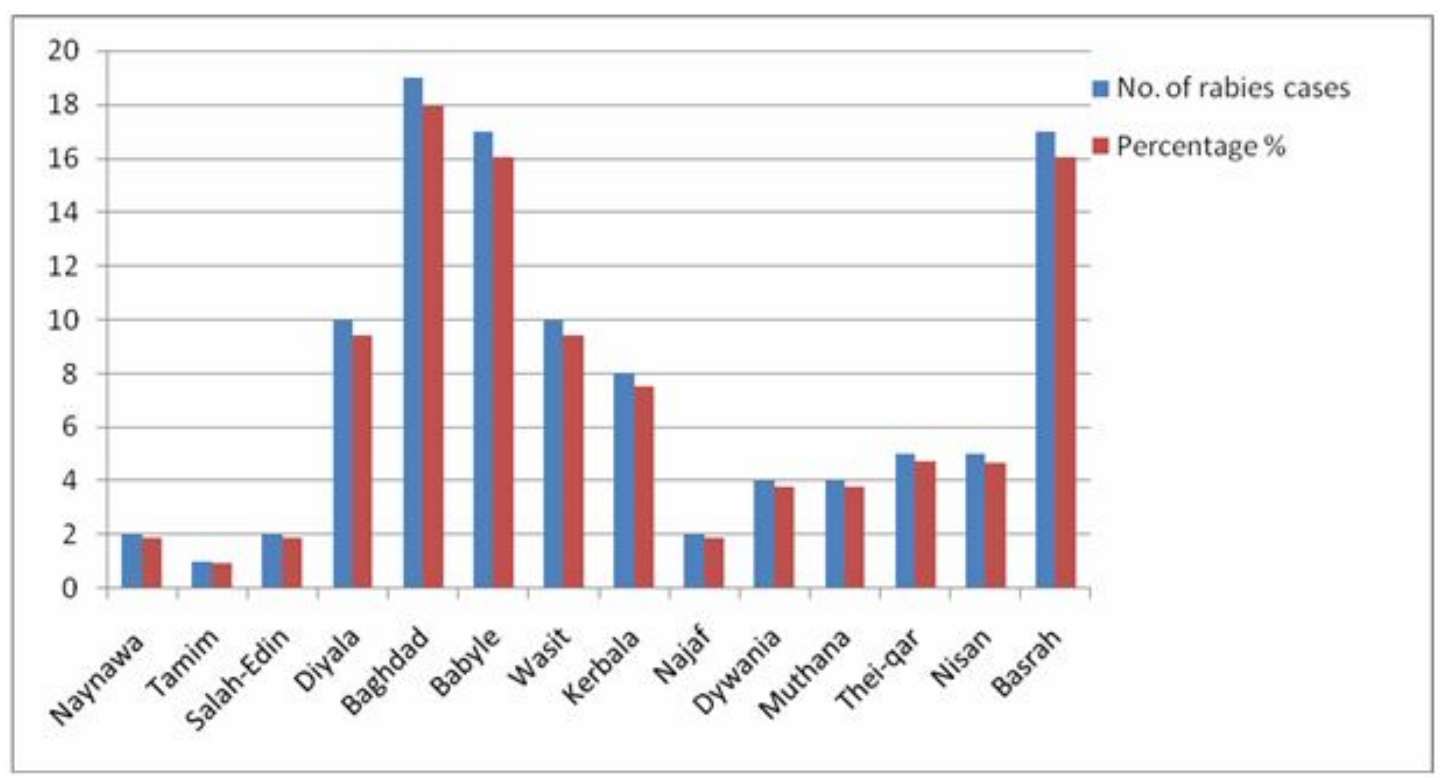

Figure (1) Percentage of rabies cases according to Iraqi governorates (2006-2010).

The results show that the highest percentage $(18.12 \%)$ of dog bite victims per 5 years of the study was reported in Baghdad city, followed by Babyle (15.41\%).(Figure 2)

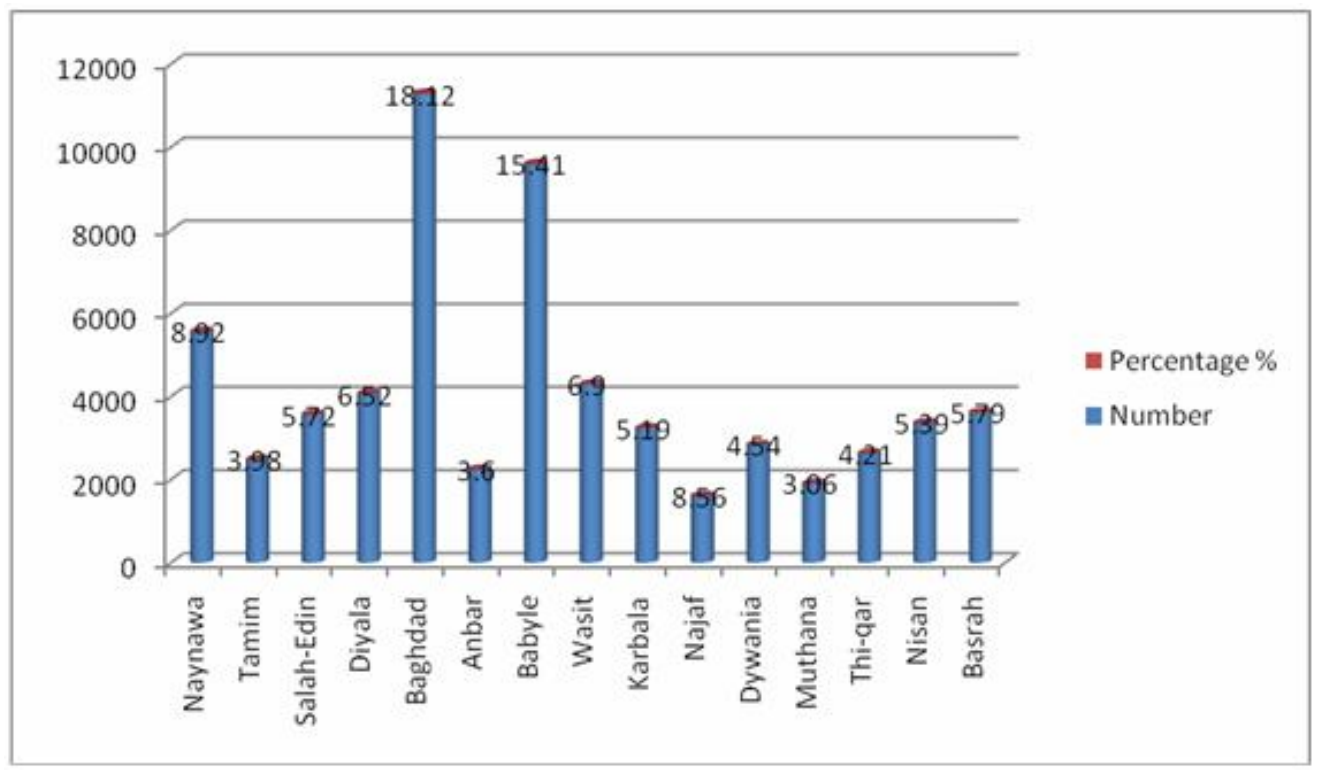

Figure (2) Distribution of dog bites victims according to the Iraqi governorates 
The monthly distribution of reported rabies cases per 5 years of the study Show that the highest percentage $(14.15 \%)$ of reported rabies cases per
5 years of the study was during October, followed by $(13.2 \%$ ) during May. (Figure 3 ).

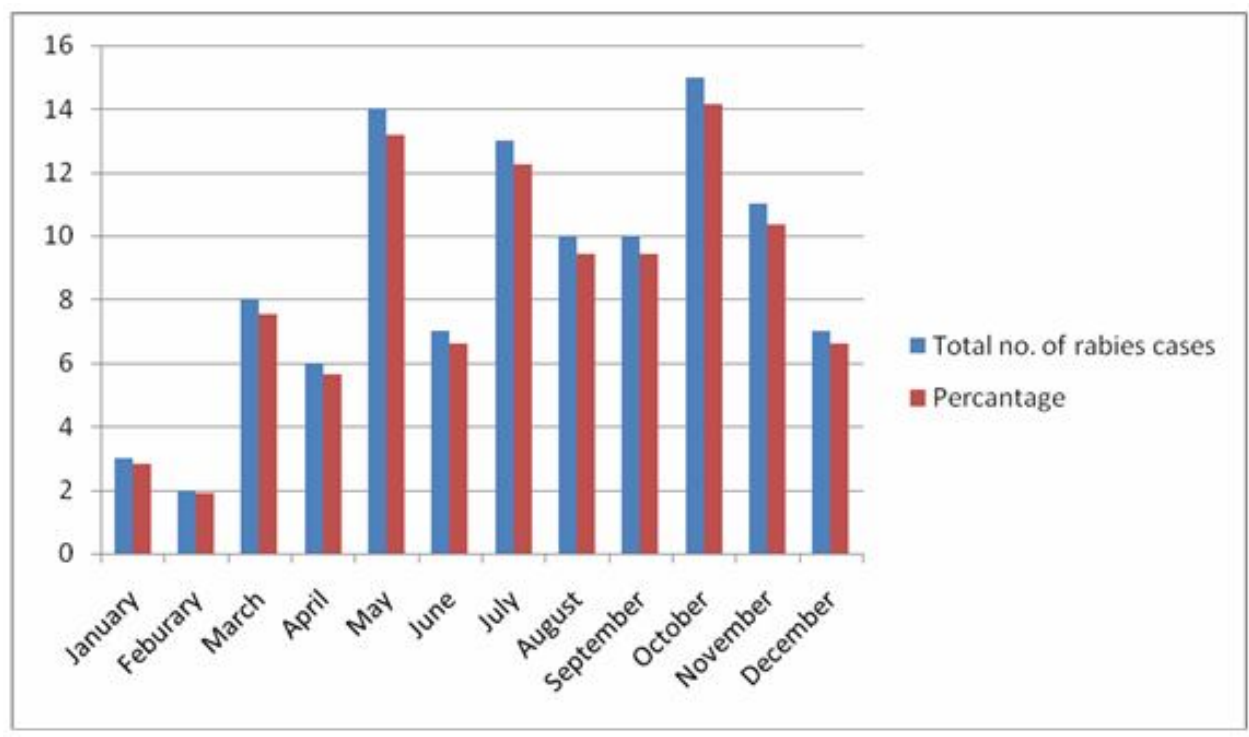

Figure (3) monthly distribution of reported rabies cases per 5 years of the study.

\section{Discussion:}

In this retrospective study, information on the status of rabies over the period of (2006-2010) is presented. In Iraq there is a high risk of falling ill from rabies which derives mainly from infected dogs (11), this could be explained due to poor management of dogs in particular the free movement of dogs, which increases their risk of contracting rabies (14). In Iraq as many as 250 cases registered in the peak year (1991). While In India for example about 20,000 human rabies deaths are estimated to occur every year (11).

The epidemiological profile of patients revealed that men were affected more than women ,this could explained due to the fact that men are more likely to go out of their homes for work as compared with women, also many studies $(15,16,17)$ showed the predominance of male patients among people living in Ghana, Ethiopia and Bugando respectively.

Children are considered to be at high risk for rabies exposure, this could be explained due to their small stature that makes extensive bites more likely, or they are attracted to animals and there is the remote possibility that they do not report a possible exposure (18). Mazigo DH, et al conducted 5 year survey of hospitalized rabies cases in Bugando, Tanzania hospitals, children < 18 years of age constituted $35 \%$ of the total number of cases (17), while in Texas (19) the highest number of humans exposed to rabid skunks was between 36 and 50 years.

Dog bites are registered yearly over different Iraqi provinces and was at maximum number in Baghdad city, this could be related to many factors such as high population density, high number of stray dogs, especially around sewage canals and weak killing attacks implemented due to security condition of the country(7).

In Spain (20) reported that population density did exert a significant effect on the incidence of rabies. In our study It seems that there was no evident monthly variations towards the occurrence of rabies, this information suggests that dogs appear to bite at a constant rate throughout the year with constant risk of 
contracting rabies by humans from the bite of these dogs, similar finding was reported in Ethiopia (16), there was no significant distribution of rabid dogs, in contrast there seems to be a cyclic pattern of distribution of the outbreaks of rabies cases that seemed to cluster around April and September, corresponding to breading seasons for dogs in Zaira, Nigeria(21).

In Texas the number of rabid skunks peaked at March and April (19), while in Nigeria more cases of rabies appeared during the dry months of the year. Also the increase in rabies test submission in the summer months, is consisted with an increased incidence of animal bites in these months (21).

\section{Conclusion:}

Having discussed the results of the study, the followings are concluded:

1- The persistence of rabies as public health problem in Iraq.

2- Dogs are responsible in maintaing the continuous persistence as well dissemination of rabies in the country.

3- The total number of registered rabies cases in Iraq during the included study period (2006-2010) was equal to 106 cases. The highest number (27) cases were during the year (2009).

4- The predominance of male cases compared to females with male to female ratio $6: 1$.

5- People at risk were mainly children below 10 years of age.

6- Distribution of rabies cases according to Iraqi governorates were highest in Baghdad city and this is corresponding directly to the highest number of dog bite victims also in Baghdad city..

7- A clear seasonal variation in rabies cases did not exist.

\section{Recommendations:}

1-Health education to initiate awareness of people towards dog bites.
2-Vaccination of dogs against rabies especially before the breeding seasons.

3-Control of stray and free roaming dogs would reduce the incidence of rabies.

4- Formulation and institution of appropriate rabies control policies.

5-Efforts should be made to fully incorporate rabies control activities to all levels of the health services, aligning them with other public health programes.

\section{$\underline{\text { References: }}$}

1.Drew WL (2004). "Chapter 41: Rabies". In Ryan KJ, Ray CG (editors). Sherris Medical Microbiology (4th ed.). McGraw Hill. pp. 597600.

2- Cotran RS, Kumar V, Fausto N, et al. (2005). Robbins and Cotran Pathologic Basis of Disease (7th ed.). St. Louis: Elsevier/Saunders. pp. 1375.

3-Nandi S, Kumar M. (2010)' Development in immunoprophylaxis against Rabies for animals and humans' .AJMB,volume 2, Issue 1, pages:3 to 21 .

4-Fayaz A "The disease with vector or reservoir Rabies". In Assisi F,Hatami H, Janghorbani M . (2004) "Epidemiology and control of prevalent Disease in Iran" $2^{\text {nd }}$ ed. Tehran, Nashre estiagh ; 542-557.

5-WHO in the Eastern Mediterranean Region . "Annul report of Regional Office, Al- Exandria (2003) “ WHO Regional office for Eastern Mediterranean Region.

6-Alavil SM , Alavi L(2009). "Ten years survey of animals bites in Khuzestan" Park j Med Sci. 25 (3): $370-374$.

7-Epidemiological situations and Diagnosis of Rabies in Iraq ( 2007)." WWW. Err. Middle east.

8-Hampson K, Dobson A, Kaare M, Dushoff J, Magoto M, Sindoya E, Cleaveland S( November 2008).Rabies exposure , post-exposure prophylaxis and deaths in a Region of Endemic Canine Rabies.Issue of Plos Neglected Tropical Diseases. 
9-Singh CK, Sauhu BS(2007),.Epidemiological ivestigation of rabies in Punjab. Indian $\mathbf{J}$ Animal Sci, 77: 653-638.

10- Hoque M, Islam T,Das SC, Jabeen N(2006),An overview of rabies in man and animals.Intas Polivet;7:388-398.

11-Korzenieewski K. The epidemiological situation in Iraq. Przegl Epidemioi; 60: 845-855.

12-Zinsstag J, Durr S" sep, (2009). Transmition dynamics and economics of rabies control in dogs and humans in the African city. Proc Nati Acad Sci Journal, vol:106(35),.

13-Agarwal N, Reddajah VP.( 2004).Epidemiology of dog bites. A community based study in India. Tropical Doct, 34(2): 76-80,

14-Cleavaland S, Kaare M, Knobel D, Laurenson MK(2006). Canine vaccination providing broader benefits for disease control. Vet Microbiol 117: 43-50.

15- Belcher WD, Wurapa FK And Autora C.O.D"( 2000) Endemic Rabies in Ghana" AM. J. Trop. Med. Hyg. 25(5), 724-729,

16-Yimer E, Newayeselassie B, Teferra B, MekonnenY, BogaleY. Zewde B, Beyene M,
Bekele.(2002) A.Situation of Rabies in Ethiopia: A retrospective study 1990-2000,Ethiop. J. Health Dev.;16(1):105-112]

17-Mazigo DH, Okuma OF, Kweka JE, and Mnyone LL(2010), Retrospective analysis of suspected rabies cases reported at Bugando referral hospital ,mwenza, Tanzania .J Giob Infect Dis,; 2(3) :216-220.

18-Mac Bean CE, Taylor DM, Asbby K. (2007) Animals and human bite injuries in Victoria (1993-2004). Med J Aust.,186(1) 38-40.

19-Oertli HE, Wilson PJ, Hunt PR (2009) Epidemiology of rabies in Skunks in Texas.JAM Vet Med Assoc,. March 1, 234(50:610-20.

20-Rsado B, Garcia-Belengure S, Leon M and Palacio J( 2009) . A comprehensive study of dog bites in Spain( 1995-2004). The Vet J , Vol 197, Issue:3, pp:383.

21-Ezcokoli CD, Umoh JU. (1987) Epidemiology of rabies in northern Nigeria Transactions of the Royan Society of Tropical Medicine and Hygiene. Volume 81, Issue 2, Pp 268-272,

داء الكلب هو اكثر الامراض المثتركة الفيروسية المميتة التي تتنقل الى جسم الانسان من خلال لعاب اللبائن المصابة. يستوطن المرض في العراق خصوصا" في المناطق القروية. انجزت دراسة مقطعية رجعية لغرض الحصول على تحليل لاصـابات داء الكلب على مدى خمسة اعوام (2006 -2010) في وحدة الامراض المشتركة الخاصـة بمركز السيطرة على الامراض الانتقالية في محافظة بغداد

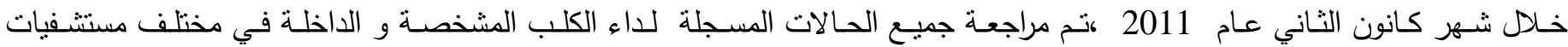
المحافظات العراقية و من بعد ذلك تم تحليل المعلومات احصائيا". اظهرت النتائج بان العدد الكلي لاصـابات داء الكلب المسجلة في العراق خلال سنوات الدراسة المشمولة كان مساويا" (106) اصابة ، العدد الاكبر و هو (27) اصابة كانت في عام (2009) ، اظهر النمط الوبائي للمرضى المصابين اغلبية الذكور (91) اصابة مقارنة بالاناث(15) اصابة ـ الاشخاص المرشحين للخطورة هم الاطفال دون العشر سنوات من العمر (35.8\%) ـ كما اظهر توزيع الاصـابات حسب المحافظات العراقية النسبة الاكبر في محافظة بغداد (17.92\%) و هو يتتاسب طرديا" مع النسبة الاكبر من ضحايا عضات الكلاب(18.12\%) ايضا" في محافظة بغداد، بينما اظهرالتوزيع الشهري لوقوع الاصابات عدم وجود ابي تغيرات موسمية واضحة. تم تقديم التوصيات بالتقيف الصحي لزيادة وعي الناس نحو المشكلة ،السيطرة على الكلاب السائبة و دمج برنامج السيطرة على داء الكلب ضمن مهام الرعاية الصحية الاولية . 